\title{
Effect of In-Situ Moisture Conservation Practices on Soil Moisture Content of Rainfed Bt Cotton (Gossypium hirsutum L.)
}

\author{
S. Ganapathi*, S. Bharathi, M. Sree Rekha and K. Jayalalitha \\ Department of Agronomy, Agricultural College, Bapatla, India \\ *Corresponding author
}

\section{A B S T R A C T}

\begin{tabular}{|c|}
\hline Keywords \\
\hline $\begin{array}{l}\text { Recommended dose of } \\
\text { fertilizer, } \text { in- situ, Soil } \\
\text { moisture conservation } \\
\text { and Foliar nutrition }\end{array}$ \\
\hline Article Info \\
\hline $\begin{array}{l}\text { Accepted: } \\
\text { 20 September } 2018 \\
\text { Available Online: } \\
10 \text { October } 2018\end{array}$ \\
\hline
\end{tabular}

\section{Introduction}

Cotton "white gold" is an important fibre as well as cash crop of India. In India, $B t$ cotton is grown in an area of $12.2 \mathrm{~m}$. ha with an annual production of 377 lakh bales and a productivity of $524 \mathrm{~kg} \mathrm{lint} \mathrm{ha}{ }^{-1}$. In the state of Andhra Pradesh, Bt cotton occupies an area of 5.44 lakh hectares with an annual production of 22 lakh bales and productivity of $688 \mathrm{~kg}$ lint ha ${ }^{-1}$ (AICCIP, Annual Report, 2017-2018).

In Andhra Pradesh, $B t$ Cotton is mainly grown under rainfed condition. The vagaries of monsoon have maligned even in the assured rainfall areas in the recent years. Cotton, being a long duration crop, needs a fairly sufficient soil moisture to sustain the growth at later stages of reproductive phase. In this backdrop, efficient utilization of rain water plays a pivotal role which can be achieved by various agronomic management practices, of which in-situ moisture conservation is the most important one that reduce the runoff there by storing more soil moisture (Asewar et al., 2008).

In-situ rain water conservation practice like opening furrows in between rows, often help in conserving soil moisture and ultimately enhance water use efficiency as well. The cost effective technologies for efficient utilization of rain water management as in - situ moisture conservation comprising the opening of furrow, may prove vital in enhancing and stabilizing the yield (Gokhale et al., 2011). 
The significance of in-situ soil moisture conservation measures is to conserve maximum possible rainwater at a place where it falls and make effective efficient use of it. The practices of opening furrow in between row of crop is also beneficial for improving the drainage system in field during the high rainfall period and for decomposing the added biomass later on. Ridge may serve as microwatershed accumulating water in furrow. Practices of making ridge by opening furrow may have an advantage in concentration of more rain water on the bed which enrich soil moisture content (Gidda and Morey, 1981) and the yield levels could be increased (Redder et al., 1991).

\section{Materials and Methods}

A field experiment was conducted during kharif 2017-18 at Regional Agricultural Research Station, Lam, Guntur, the soil of the experimental field was clay in texture, neutral in reaction (7.45), low in total nitrogen and high in available phosphorus and potassium. The experiment was laid out in a randomized block design with three replications and eight treatments. The allocated treatments were $\mathrm{T}_{1}$ $100 \% \operatorname{RDF}(120: 60: 60) \quad \mathrm{NPK} \mathrm{kg} \mathrm{ha}{ }^{-1} \mathrm{~T}_{2}-$ $125 \%$ RDF (150:75:75) NPK kg ha ${ }^{-1}, \mathrm{~T}_{3}-100$ $\% \operatorname{RDF}(120: 60: 60)+$ opening furrow for every row during last intercultural operation, $\mathrm{T}_{4}-125 \% \operatorname{RDF}(150: 75: 75)$ + opening furrow for every row during last intercultural operation, $\mathrm{T}_{5}-100 \%$ RDF ( 120:60:60)+ Foliar nutrition with $2 \% \mathrm{KNO}_{3}$ at square formation, flowering and boll development, $\mathrm{T}_{6}$ - 125\% RDF (150:75:75) + Foliar nutrition with $2 \% \mathrm{KNO}_{3}$ at square formation, flowering and boll development, $\mathrm{T}_{7}-100 \% \mathrm{RDF}$ (120:60:60)+ opening furrow for every row during last intercultural operation + foliar nutrition with $2 \% \mathrm{KNO}_{3}$ at square formation, flowering and boll development and $\mathrm{T}_{8}-125 \%$ $\operatorname{RDF}$ ( 150:75:75)+ opening furrow for every row during last intercultural operation + Foliar nutrition with $2 \% \mathrm{KNO}_{3}$ at square formation, flowering and boll development. Phosphorus was applied as basal through SSP as per the treatments. Nitrogen and potassium was applied through urea and Murete of potash 1/3 at basal, $1 / 3$ at 60 DAS and $1 / 3$ at square initiation stage. The hirsutum Bt hybrid (jadoo) was sown at spacing of $105 \mathrm{~cm}$ x 60 $\mathrm{cm}$ on 15 july, 2017-18. The data on plant height, boll weight and number of bolls per plant were recorded from randomly selected five plants from each plot and seed cotton yield was recorded on /plot basis. other agronomic practices and plant protection measures were followed as per recommendation.

\section{Results and Discussion}

The soil moisture (\%) at different crop growth stages of cotton was recorded (Table 1). The soil moisture percentage decreased gradually from 60 DAS to 120 DAS. In the study, the nutrient management and moisture conservation practices influenced the soil moisture percentage Fig. 4.2 and Table 4.5. A total rainfall of $(466 \mathrm{~mm})$ was received during the crop growing season in 36 rainy days. The moisture conservation treatments of opening the furrows were imposed during the last intercultural operation and the data on soil moisture was recorded at 60, 90 and 120 DAS revealed that maximum soil moisture (\%) was recorded in $125 \%$ RDF (150:75:75) + opening furrow for every row during last intercultural operation + foliar nutrition with $2 \% \mathrm{KNO}_{3}$ at square formation, flowering and boll development, $100 \%$ RDF (120:60:60) +opening furrow for every row during last intercultural operation + foliar nutrition with $2 \% \mathrm{KNO}_{3}$ at square formation, flowering and boll development, 125\% RDF (150:75:75) +opening furrow for every row during last intercultural operation and $100 \%$ RDF (120:60:60) + opening furrow for every row during last intercultural operation and the 
lowest soil moisture (\%) was recorded with $100 \%$ RDF (120:60:60). The availability of more soil moisture in these treatments might be due to practice of opening furrows which acts as drainage during heavy rains and serves for in situ infiltration and retention of moisture during the dry spells. These results are in conformity with Narayana et al., ( 2011), Tayade and Meshram ( 2013) and Paslawar and Deotalu (2015). At harvest the maximum drymatter accumulation ( $11915 \mathrm{~kg} \mathrm{ha}^{-1}$ ) (Table 1) was recorded with $125 \%$ RDF (150:75:75) + opening furrow for every row during last intercultural operation + foliar nutrition with $2 \% \mathrm{KNO}_{3}$ at square formation, flowering and boll development. The lowest drymatter accumulation (9391 $\mathrm{kg} \mathrm{ha}^{-1}$ ) was recorded at 100\% RDF (120:60:60) NPK kg $\mathrm{ha}^{-1}$. The increased drymatter accumulation with $125 \%$ RDF might be due to the fact that increased fertilization made the plants more efficient in photosynthetic activity by enhancing the carbohydrate metabolism and hence resulted in increased drymatter accumulation. Squaring, blooming and boll development are the stages when cotton requires higher nutrition and augment of nutrient supply through foliar application at such critical stages help in increased growth parameters especially drymatter accumulation, which might be due to adequate supply of nutrients with foliar application (Rajendran et al., 2011; Devraj et al., 2011; Sandeep et al., 2015 and Santhosh et al., 2016).

At harvest, the maximum number of sympodial branches per plant (Table 1) (23.2) were recorded with application of $125 \% \mathrm{RDF}$ (150:75:75) + opening furrow for every row during last intercultural operation + foliar nutrition with $2 \% \mathrm{KNO}_{3}$ at square formation, flowering, and boll development. The lowest sympodial branches (16.8) per plant was recorded with 100\% RDF (120:60:60) NPK kg $\mathrm{ha}^{-1}$. Similar trend in number of sympodial branches was recorded at 60, 90, and 120 DAS as well. The more number of sympodial branches per plant with opening of furrows at every row might be due to increase the soil moisture availability to crops as well as increase in the nutrient use efficiency. Similar results were reported made by Santhosh et al., (2016), Narayana et al., (2011) and Rajendran et al., (2011).

The maximum numbers of bolls per plant (78.1) were recorded (Table 1) with 125\% RDF (150:75:75) +opening furrow for every row during last intercultural operation + foliar nutrition with $2 \% \mathrm{KNO}_{3}$ at square formation, flowering and boll development and lowest recorded with $100 \%$ RDF (120:60:60) NPK kg $\mathrm{ha}^{-1}\left(56.7\right.$ bolls plant ${ }^{-1}$ and 63.7 bolls $\left.\mathrm{m}^{2}\right)$. The increase in boll number per plant was obtained with opening furrow for every row during last intercultural operation might be due to better soil moisture retention that might have helped for better utilization of nitrogen, phosphorus and potassium fertilizer applied (Keshava et al., 2013; Saravanan et al., 2012 and Nehra and Yadav, 2013).

Significantly affected by soil moisture conservation practices Maximum seed cotton yield (3411 $\mathrm{kg} \mathrm{ha}^{-1}$ ) was recorded with (Table 1) $125 \% \operatorname{RDF}(150: 75: 75)$ +opening furrow for every row during last intercultural operation + foliar nutrition with $2 \% \mathrm{KNO}_{3}$ at square formation, flowering and boll development and lowest seed cotton yield (2285 $\mathrm{kg} \mathrm{ha}^{-1}$ ) was recorded with RDF (120:60:60) NPK kg ha ${ }^{-1}$ and stalk yield of cotton as influenced by nutrient management and soil moisture conservation practices Fig. 4.4 and Table 4.9 presented maximum stalk yield was $\left(5877 \mathrm{~kg} \mathrm{ha}^{-1}\right)$ recorded with $125 \%$ RDF (150:75:75)+opening furrow for every row during last intercultural operation + foliar nutrition with $2 \% \mathrm{KNO}_{3}$ at square formation, flowering and boll development and Lowest stalk yield was (5282 kg ha ${ }^{-1}$ ) was recorded with RDF (120:60:60). 
Table.1 Effect of in-situ soil moisture conservation practices on growth parameters, yield attributes and yield of Bt cotton

\begin{tabular}{|c|c|c|c|c|c|c|c|c|c|}
\hline \multirow[t]{2}{*}{ Treatments } & \multicolumn{3}{|c|}{ Soil Moisture (\%) } & \multirow{2}{*}{\begin{tabular}{l}
$\begin{array}{l}\text { Dry } \\
\text { matter } \\
\text { accumu } \\
\text { lation } \\
\left(\mathrm{kg} \mathrm{ha}^{-1}\right)\end{array}$ \\
\multicolumn{1}{c}{ At } \\
Harvest
\end{tabular}} & \multirow{2}{*}{$\begin{array}{l}\text { Sympodi } \\
\text { al } \\
\text { branches } \\
\text { plant }^{-1}\end{array}$} & \multirow{2}{*}{\begin{tabular}{l}
$\begin{array}{l}\text { Number } \\
\text { of } \\
\text { bolls } \\
\text { plant }^{-1}\end{array}$ \\
\multicolumn{1}{c}{ At } \\
Harvest
\end{tabular}} & \multirow{2}{*}{$\begin{array}{l}\text { Seed } \\
\text { cotton } \\
\text { yield } \\
\left(\mathrm{kg} \mathrm{ha}^{-1}\right)\end{array}$} & \multirow{2}{*}{$\begin{array}{l}\text { Stalk } \\
\text { yield } \\
(\mathrm{kg} \\
\left.\mathrm{ha}^{-1}\right)\end{array}$} & \multirow[t]{2}{*}{$\begin{array}{l}\text { GOT } \\
(\%)\end{array}$} \\
\hline & $\begin{array}{c}\text { 60 } \\
\text { DAS }\end{array}$ & $\begin{array}{c}90 \\
\text { DAS }\end{array}$ & $\begin{array}{c}\text { At } \\
\text { Harvest }\end{array}$ & & & & & & \\
\hline$T_{1^{-}} \quad 100 \%$ RDF (120:60:60) NPK & 9.4 & 8.6 & 4.3 & 9391 & 16.8 & 56.7 & 2285 & 5282 & 33.3 \\
\hline$T_{2^{-}} \quad 125 \%$ RDF(150:75:75) NPK & 10.0 & 9.4 & 4.1 & 9788 & 19.4 & 64.0 & 2460 & 5505 & 33.2 \\
\hline $\begin{array}{l}\text { T3- T1+ Opening furrow for every row during last } \\
\text { intercultural operation. }\end{array}$ & 14.1 & 13.6 & 8.2 & 9655 & 18.2 & 59.6 & 2519 & 5431 & 33.9 \\
\hline $\begin{array}{l}\text { T4- T2+ Opening furrow for every row during last } \\
\text { intercultural operation. }\end{array}$ & 14.3 & 13.9 & 8.3 & 10053 & 20.4 & 70.8 & 2947 & 5654 & 33.8 \\
\hline $\begin{array}{l}\text { T5- T1+ Foliar nutrition with } 2 \% \text { KNO3 at square } \\
\text { formation, flowering, and boll development. }\end{array}$ & 10.2 & 8.8 & 5.1 & 9920 & 19.6 & 68.4 & 2831 & 5580 & 33.3 \\
\hline $\begin{array}{l}\text { T6- T2+ Foliar nutrition with } 2 \% \text { KNO3 at square } \\
\text { formation, flowering, and boll development. }\end{array}$ & 10.0 & 9.7 & 4.6 & 11283 & 21.4 & 74.1 & 3266 & 5803 & 33.1 \\
\hline $\begin{array}{l}\text { T7- T3+ Foliar nutrition with } 2 \% \text { KNO3 at square } \\
\text { formation, flowering, and boll development. }\end{array}$ & 14.1 & 13.4 & 8.3 & 10650 & 20.8 & 71.3 & 3177 & 5712 & 33.5 \\
\hline \multirow{2}{*}{$\begin{array}{l}\text { T8- T4+ Foliar nutrition with } 2 \% \text { KNO3 at square } \\
\text { formation, flowering, and boll development. }\end{array}$} & 14.8 & 13.9 & 8.4 & 11915 & 23.2 & 78.1 & 3411 & 5877 & 33.1 \\
\hline & 0.3 & 1.0 & 0.4 & 682.3 & 0.6 & 4.8 & 96.2 & 131.5 & 2.2 \\
\hline $\mathrm{CD}(\mathrm{P}=0.05)$ & 1.1 & 3.1 & 1.5 & 1964.7 & 2.4 & 7.8 & 292.0 & 394.6 & NS \\
\hline CV $(\%)$ & 5.3 & 15.8 & 13.3 & 11.4 & 5.2 & 12.3 & 5.8 & 12.1 & 11.5 \\
\hline
\end{tabular}


Table.2 Economics of different treatments of Bt cotton as influenced by nutrient management and moisture conservation practices

\begin{tabular}{|c|c|c|c|c|c|}
\hline Treatments & $\begin{array}{c}\text { Seed } \\
\text { cotton } \\
\text { yield }(\mathrm{kg} \\
\left.\mathrm{ha}^{-1}\right)\end{array}$ & $\begin{array}{c}\text { Gross } \\
\text { Returns } \\
\left(\text { Rs. ha } \text { ha }^{-1}\right)\end{array}$ & $\begin{array}{c}\text { Cost of } \\
\text { cultivation } \\
\left(\text { Rs. ha } \mathbf{h}^{-1}\right)\end{array}$ & $\begin{array}{c}\text { Net } \\
\text { Returns } \\
\left(\text { Rs. ha' } \text { ha }^{-1}\right.\end{array}$ & $\begin{array}{l}\text { B:C } \\
\text { Ratio }\end{array}$ \\
\hline$T_{1}-100 \%$ RDF (120:60:60) NPK & 2285 & 99401 & 42231 & 57169 & 1.35 \\
\hline $\mathrm{T}_{2-125 \%} \mathrm{RDF}(150: 75: 75) \mathrm{NPK}$ & 2460 & 107029 & 46590 & 60439 & 1.30 \\
\hline$T_{3^{-}} T_{1}+$ Opening furrow for every row during last intercultural operation. & 2519 & 109613 & 44809 & 64803 & 1.44 \\
\hline$T_{4}-T_{2}+$ Opening furrow for every row during last intercultural operation. & 2947 & 128219 & 51000 & 77219 & 1.51 \\
\hline $\begin{array}{l}\mathrm{T}_{5-} \mathrm{T}_{1}+\text { Foliar nutrition with } 2 \% \mathrm{KNO}_{3} \text { at square formation, flowering, and boll } \\
\text { development. }\end{array}$ & 2831 & 123170 & 47103 & 76067 & 1.61 \\
\hline $\begin{array}{l}\mathrm{T}_{6-} \mathrm{T}_{2}+\text { Foliar nutrition with } 2 \% \mathrm{KNO}_{3} \text { at square formation, flowering, and boll } \\
\text { development. }\end{array}$ & 3266 & 142086 & 52017 & 90069 & 1.73 \\
\hline $\begin{array}{l}\mathrm{T}_{7-} \mathrm{T}_{3}+\text { Foliar nutrition with } 2 \% \mathrm{KNO}_{3} \text { at square formation, flowering, and boll } \\
\text { development. }\end{array}$ & 3177 & 138202 & 51368 & 86835 & 1.69 \\
\hline $\begin{array}{l}\mathrm{T}_{8^{-}} \mathrm{T}_{4}+\text { Foliar nutrition with } 2 \% \mathrm{KNO}_{3} \text { at square formation, flowering, and boll } \\
\text { development. }\end{array}$ & 3411 & 148380 & 53174 & 95205 & 1.79 \\
\hline S.Em \pm & 96.2 & 4188.41 & - & 4188.41 & 0.084 \\
\hline $\mathrm{CD}(\mathrm{P}=0.05)$ & 292.0 & 12704.3 & - & 12704.3 & 0.25 \\
\hline CV (\%) & 5.8 & 5.8 & - & 9.5 & 9.3 \\
\hline
\end{tabular}


NPK kg ha ${ }^{-1}$ the increase in stalk yield might be due to favorable effect of macro nutrients on cell elongation, cell wall thickening, stem and leaf thickness and more of leaf and stem weight. Similar results were observed by Halemani et al., (2004) and Rajendran et al., (2011) and Sandeep et al., (2015).

The higher gross returns, net income and benefit cost ratio were obtained (Table 2) with $125 \%$ RDF (150:75:75) +opening furrow for every row during last intercultural operation + Foliar nutrition with $2 \% \mathrm{KNO}_{3}$ at square formation, flowering, and boll development and was similar with $125 \%$ RDF (150:75:75) + foliar nutrition with $2 \% \mathrm{KNO}_{3}$ at square formation, flowering and boll development followed by 100\% RDF (120:60:60)+ opening furrow for every row during last intercultural operation + foliar nutrition with $2 \% \mathrm{KNO}_{3}$ at square formation, flowering, and boll development and125\% RDF(150:75:75)+ opening furrow for every row during last intercultural operation and boll development. Which, might be due to higher seed cotton yield obtained per unit area. Similar result obtained by Narayana et al., (2011) and Santhosh et al., (2016).

\section{References}

AICCIP. 2017-18. All India Coordinated Cotton Improvement Project - Annual report. Coimbatore, Tamil Nadu.

Asewar, B.V., Jadhav, A.S and Khan, Y.A. 2008. Effect of in situ water management and intercropping systems on yield of rainfed cotton. Journal of Cotton Research and Development. 22 (2): 173-175.

Devraj, Bhattoo, M.S., Duhan, B.S., Kumari, P and Jain, P.P. 2011. Effect of crop geometry and fertilizer levels on seed cotton yield and nutrient uptake of $B t$ cotton under irrigated conditions.
Journal of Cotton Research and Development. 25 (2): 176-180.

Gidda, V.R and Morey, D.K. 1981. Effect of tillage practices and antitranspirant on relative water content, leaf water potential and yield of rainfed cotton (SRT-I). Journal of Maharashtra Agricultural Universities (India).

Gokhale, D.N., Shinde, V.S., Gadade, G.D., Sawargaonkar, G.L and Zade, K.K. 2011. Sustaining rainfed $B t$ cotton (Gossypium hirsutum L.) productivity through moisture conservation and integrated nutrient management techniques. Journal of Cotton Research and Development. 25 (2): 197-201.

Helemani, H.L., Hallikeri, S.S., Antravali, M.B. and Nandagavi, R.A. 2002. Studies on dry sowing and rain water harvesting in rainfed cotton. Journal of Indian Society and Cotton Improvement. 27: 94-99.

Keshava, C.S., Goroji, P.T., Doreswamy, C and Naresh, N.T. 2014. Assessment of foliar spray of potassium nitrate on growth and yield of cotton. Karnataka Journal of Agricultural Sciences. 26 (2).

Narayana, E., Aparna, D and Mridula, G. 2011. Response of Bt cotton (Gossypium hirsutum L) for integrated rain water and nutrient management. Journal of Cotton Research and Development. 25 (1): 68-70.

Nehra, P.L and Yadav, P.S. 2013. Effect of moisture conservation and nutrient management for improvement in productivity and fibre quality of cotton. Journal of Cotton Research and Development. 27 (1): 70-72.

Paslawar, A. N and Deotalu, A. S. 2015. Impact of soil moisture conservation practices and nutrient management under high density planting system of cotton. The International Journal of Engineering and Science. 4 (9): 34-36. 
Rajendran, K., Mohamed, M.A and Vaiyapuri, K. 2011. Influence on growth, yield attributes and yield of $B t$ cotton by soil and foliar application of nutrients. Madras Agricultural Journal. 98 (1/3): 67-68.

Redder, G.D., Itnal, C.J., Surkod, V.S and Baridar, S.N. 1991. Compartment bunding an effective in- situ moisture conservation practice on medium deep block soil. Indian Journal of Soil Conservation. 19: 1-5.

Sandeep, R., Mehta, A.K., Thakral, S.K and Mahesh, K. 2015. Effect of nitrogen and phosphorus levels on growth, yield attributes and yield of $B t$ cotton. Journal of Cotton Research and Development. 29 (1): 76-78.
Santhosh, U.N., Satyanarayan, R., Biradar, S.A., Desai, B.K., Halepyati, A.S and Koppalkar, B.G. 2016. Response of soil and foliar nutrition on Bt cotton (Gossypium hirsutum L.) quality, yield parameters and economics under irrigation. Journal of Cotton Research and Development. 30 (2): 205-209.

Saravanan, M., Venkitaswamy, $\mathrm{R}$ and Rajendran, K. 2012. Influence of foliar nutrition on seed cotton yield and quality of $B t$ cotton. Madras Agricultural Journal. 99 (4/6): 332-334.

Tayade, A. S and Meshram, M. K. 2013. Impact of dry sowing and in-situ moisture conservation on productivity of rainfed cotton. Journal of Cotton Research and Development. 27 (1): 6669.

\section{How to cite this article:}

Ganapathi, S., S. Bharathi, M. Sree Rekha and Jayalalitha, K. 2018. Effect of In-Situ Moisture Conservation Practices on Soil Moisture Content of Rainfed Bt Cotton (Gossypium hirsutum L.). Int.J.Curr.Microbiol.App.Sci. 7(10): 2832-2838. doi: https://doi.org/10.20546/ijcmas.2018.710.329 